\title{
Higher frequency of regulatory T cells in granulocyte colony-stimulating factor (G-CSF)-primed bone marrow grafts compared with G-CSF-primed peripheral blood grafts
}

\author{
Xiang-Yu Zhao ${ }^{1 \dagger}$, Yu-Tong Wang ${ }^{1 \dagger}$, Xiao-Dong Mo ${ }^{1}$, Xiao-Su Zhao', Ya-Zhe Wang ${ }^{1}$, Ying-Jun Chang ${ }^{1}$ \\ and Xiao-Jun Huang ${ }^{1,2^{*}}$
}

\begin{abstract}
Background: Regulatory T cells (Treg) in allografts are important for the prevention of graft-versus-host disease (GVHD) post-transplantation. The aim of this study was to compare the contents of Tregs and effector T cells in granulocyte colony-stimulating factor (G-CSF)-primed bone marrow grafts (G-BM) and peripheral blood grafts (G-PB).

Method: G-BM and G-PB were obtained from 20 allogeneic donors. T-cell subgroups, including conventional T cells and different types of Treg cells, as well as the percentage of Ki67 expression on CD4 ${ }^{+} \mathrm{CD} 25^{\text {high }}{ }^{\text {Foxp }} 3^{+}$Treg cells, were analyzed using flow cytometry. The levels of interferon- $\gamma$ (IFN- $\gamma$ ) and interleukin-17 (IL-17) secreted by T cells stimulated with PMA and ionomycin were also determined by flow cytometry.

Results: The percentage of $\mathrm{CD} 4{ }^{+} \mathrm{CD} 25^{\text {high }} \mathrm{CD} 127^{-/ \mathrm{dim}} \mathrm{CD} 62 \mathrm{~L}^{+}$Treg cells was significantly higher in the G-BM group, with higher proportions of CD45RA ${ }^{+}$naïve Treg cells and higher expression of CD69 on Treg cells in G-BM $(P<0.05)$. The percentage of Ki67 expression in $\mathrm{CD}^{+} \mathrm{CD}_{2} 5^{\text {high }} \mathrm{Foxp}^{+}$Treg cells in G-BM was significantly higher than that on G-PB. The suppressive functions of Treg cells in inhibiting T-cell activation were comparable between G-BM and G-PB. The proportions of $\mathrm{CD}^{+} \mathrm{CD}_{25} 5^{-} \mathrm{CD} 69^{+}$Treg subsets as well as Th1 cells in G-BM were also significantly higher than those in G-PB $(P<0.001)$. The proportions of conventional T cells and Th17 effector cells were comparable in G-BM compared with those in G-PB. Thus, the ratio of conventional T cells and $C D 4^{+} \mathrm{CD} 25^{\text {high }} \mathrm{CD} 127^{-/ \text {dim }}$ regulatory T cells were lower in $\mathrm{G}-\mathrm{BM}$ than that in $\mathrm{G}-\mathrm{PB}(P=0.014)$.

Conclusion: In addition to the much higher T-cell counts in G-PB grafts that may contribute to more severe GVHD, the higher frequency of Treg cells and lower ratio of conventional T cells to Treg cells in G-BM compared with G-PB grafts might reduce GVHD post-transplantation in G-BM compared with G-PB transplantation.
\end{abstract}

Keywords: Regulatory T cells, Effector T cells, G-BM, G-PB

\section{Introduction}

Allogeneic hematopoietic stem cell transplantation (alloHSCT) is the only curative method available for malignant hematologic diseases. However, its broad application is limited by the high incidence of graft-versus-host disease (GVHD). The current allo-HSCT procedures consist

\footnotetext{
* Correspondence: huangxiaojun@bjmu.edu.cn

${ }^{+}$Equal contributors

'Peking University People's Hospital and Peking University Institute of Hematology, Beijing Key Laboratory of Hematopoietic Stem Cell

Transplantation, No. 11 Xizhimen South Street, Beijing 100044, China

${ }^{2}$ Peking-Tsinghua Center for Life Sciences, Beijing 100871, China
}

mostly of bone marrow (BM) cells or granulocyte-colony stimulating factor (G-CSF)-primed peripheral blood stem cells (G-PB) or G-CSF-primed bone marrow (G-BM). Although both G-BM and G-PB contain large numbers of mature donor $\mathrm{T}$ cells that could cause GVHD [1], clinical data have demonstrated that patients undergoing G-PB transplantation were more likely to acquire severe acute GVHD refractory to prednisone and chronic GVHD (cGVHD) with a prolonged requirement for immunosuppression therapy to control symptoms compared to G-BM 
transplantation [2]. However, the underlying mechanism remains undefined.

$\mathrm{CD} 4{ }^{+} \mathrm{CD} 25^{\text {high }} \mathrm{CD} 127^{- \text {llow }}$ regulatory $\mathrm{T}$ cells (Treg cells) have been demonstrated to have immunosuppressive ability and to be key players in the regulation of immune responses [3]. Rezvanietal et al. determined that increased frequencies of $\mathrm{CD}^{+}{ }^{+} \mathrm{Foxp}^{+}$Treg cells in the peripheral blood of the donor negatively correlated with the incidence of GVHD in the graft recipient [4]. Subsequent studies have confirmed this correlation in the recipients of HLA-identical sibling and unrelated donor stem cell grafts $[5,6]$, indicating that infused donor Treg cells in graft contents appear to lessen the severity of GVHD. In addition, donor immunoregulatory $\mathrm{T}$ cells, including $\mathrm{CD} 4{ }^{+} \mathrm{CD} 25^{\text {high }} \mathrm{CD} 62 \mathrm{~L}^{+}$regulatory $\mathrm{T}$ cells and $\mathrm{CD} 4^{+}$ $\mathrm{CD} 25^{-} \mathrm{CD} 69^{+} \mathrm{T}$ cells, also contribute to decreased acute GVHD post-transplantation [7-9]. The CD4 ${ }^{+}$ $\mathrm{CD} 25^{\text {high }}{ }^{-}$D62 $\mathrm{L}^{+} \mathrm{T}$ regulatory cell subset has optimal suppressive and proliferative potential. The $\mathrm{CD}_{62} \mathrm{~L}^{+}$cell subset is a more potent suppressor than the $\mathrm{CD}^{2} 2 \mathrm{~L}^{-}$ population or unfractionated $\mathrm{CD} 4^{+} \mathrm{CD} 25^{+}$Treg cells [10]; therefore, only the $\mathrm{CD} 62 \mathrm{~L}^{+}$subpopulation of $\mathrm{CD} 4{ }^{+} \mathrm{CD} 25^{+}$ regulatory $\mathrm{T}$ cells protects from lethal acute GVHD [11]. Furthermore, CD69 is generally regarded as an activating marker, but recent studies have shown that CD69 is an immunoregulatory molecule induced following activation [12]. An additional report demonstrated that $\mathrm{CD} 4^{+} \mathrm{CD} 25^{-}$ $\mathrm{CD} 9^{+} \mathrm{T}$ cells act as a new subset of regulatory $\mathrm{CD} 4^{+} \mathrm{T}$ cells characterized by a lack of Foxp3 expression and IL10 secretion but with a high expression of CD122 and membrane-bound TGF-beta1 [13].

Previous work has demonstrated that the in vivo application of G-CSF would decrease the number of Treg cells in the bone marrow and increase the number of Treg cells in the peripheral blood [14-17]. In addition, our previous reports have demonstrated that differences existed in the immunological status between G-BM and G-PB $[14,15,18,19]$. However, until now, the Treg contents and function of G-BM and G-PB have not been comparatively analyzed. The aim of this study was to explore the contents of regulatory $\mathrm{T}$ cells, as well as the balance between the effector and regulatory arms of the immune system, including conventional $\mathrm{T}$ cells, Th17, and Th1 cells, between G-BM and G-PB.

\section{Methods}

G-CSF treatment of healthy donors and sample collection G-BM and G-PB were obtained from 20 consecutive allogeneic donors. As shown in Table 1, this group of donors, 11 men and 9 women, provided informed consent and had a median age of 29 years ranging from 18 to 54 years. Approval for this study was obtained from the Institutional Review Board and Ethical Committee of the Health Center at Peking University. Donors received recombinant G-CSF (filgrastim; Kirin Co., Ltd., Tokyo, Japan) at a dosage of $5 \mu \mathrm{g} / \mathrm{kg} / \mathrm{d}$ for 5 consecutive days. G-BM was collected on the 4th day of treatment by aspiration, and G-PB was obtained on the 5th day by leukapheresis using a continuous-flow blood cell separator (Gambro BCT, Lakewood, CO, USA; or Baxter, Chicago, IL, USA). The reason for using this protocol was that patients in our institute receive transplants composed of G-BM plus G-PB, which are harvested on days 4 and 5 , respectively $[20,21]$.

\section{Immunophenotyping, intracellular staining and multiparameter flow cytometric analysis}

Samples were stained without further separation to minimize selective losses shortly after collection. Combinations of the directly conjugated monoclonal antibodies CD3-V500, CD4-PerCP, CD56-PE, CD127-BV421, CD25PE-CY7, CD25-APC, CD62L-FITC, CD69-APC, CD45RAFITC, CCR7-PE, Ki67-FITC, Foxp3-APC (BD Bioscience, Mountain View, CA, USA), CD16-APC/CY7, HLADRAPC/CY7 (Biolegend, San Diego, CA, USA) and their relative allotypes were used in individual 8-color flow cytometry assays to analyze the immunophenotype of regulatory $\mathrm{T}$ cells and effector $\mathrm{T}$ cells.

Intracellular staining was performed using the Intracellular Staining Kit (eBioscience, San Diego, CA, USA). The expression of Ki67 was determined in freshly isolated $\mathrm{CD} 4{ }^{+} \mathrm{CD} 25^{\text {high }}{ }$ oxp $3^{+}$regulatory $\mathrm{T}$ cells. The cellular secretion and function of cytokines were determined after incubation of cells for $5 \mathrm{~h}$ with phorbol myristate acetate (PMA) $(100 \mathrm{ng} / \mathrm{ml})$ plus ionomycin $(2 \mathrm{ug} / \mathrm{ml}$, all reagents from Sigma Chemical Co., St. Louis, MO, USA) to stimulate maximal production of IL-17 and IFN- $\gamma$; GolgiStop $(0.7 \mu \mathrm{l} / \mathrm{ml})$ was added to the samples during the last 4 hours to sequester the proteins in the cytoplasm $[22,23]$.

\section{Treg cell ex vivo suppression assay}

We isolated human Treg $\left(\mathrm{CD} 4^{+} \mathrm{CD} 25^{+}\right)$and Tresp cells $\left(\mathrm{CD} 4^{+} \mathrm{CD} 25^{-}\right)$from G-BM and G-PB using a human

\section{Table 1 Donor characteristics}

\begin{tabular}{ll}
\hline Characteristics & Total $(\mathbf{n}=\mathbf{2 0})$ \\
\hline Median age at transplantation, years old (range) & $29(18-54)$ \\
Male sex, no. (\%) & $11(55 \%)$ \\
Percentage of each T cell subset in CD4+ T cells before G-CSF in the \\
peripheral blood (mean \pm SE) \\
$\mathrm{CD} 4^{+} \mathrm{CD} 25^{\text {high }} \mathrm{CD} 127^{- \text {-low }}$ regulatory T cells \\
$\mathrm{CD} 4^{+} \mathrm{CD} 25^{\text {high }} \mathrm{CD} 62 \mathrm{~L}^{+}$regulatory T cells & $3.88 \pm 0.48$ \\
$\mathrm{CD} 4^{+} \mathrm{CD} 25^{-} \mathrm{CD} 69^{+}$regulatory T cells & $3.05 \pm 0.52$ \\
$\mathrm{CD} 4^{+} \mathrm{CD} 25^{\text {high }} \mathrm{CD} 127^{+}$conventional T cells & $0.15 \pm 0.05$ \\
Th1 cells & $71.93 \pm 1.90$ \\
Th17 cells & $39.84 \pm 5.02$ \\
\hline
\end{tabular}


$\mathrm{CD} 4^{+} \mathrm{CD} 25^{+}$Regulatory $\mathrm{T}$ cell Isolation kit (Miltenyi Biotec). Tresp cells were labeled with $5 \mu \mathrm{M}$ 5,6-carboxyfluorescein diacetate succinimidyl ester (CFSE) (Biolegend). A total of $1 \times 10^{4}$ CFSE-labeled Tresp cells were cultured with unlabeled autologous Treg cells at different ratios, including 1:1, 2:1, and 4:1, in round-bottom 96-well plates in the presence of Treg Suppression Inspector consisting of Anti-Biotin MACSiBead Particles that were pre-loaded with biotinylated $\mathrm{CD} 2, \mathrm{CD} 3$, and CD28 antibodies (Miltenyi Biotec). After 5 days, an analysis of cell division was performed using the FACSCanto II system (BD Biosciences). The suppressive capacity of Treg cells toward the cocultured responder cells is expressed as the relative inhibition of the percentage of CFSE low cells $[100 \times(1-\%$ CFSE low Tresp cells in coculture/\% CFSE low Tresp alone)].

\section{Statistical analysis}

To test the differences in the regulatory $\mathrm{T}$ cells and effector $\mathrm{T}$ cells between donors treated with G-BM and G-PB, a Wilcoxon signed-rank test or paired-sample $\mathrm{T}$ test was used. $\mathrm{P}<0.05$ was considered statistically significant.

\section{Results}

Comparison of multiple regulatory T cells between G-BM and G-PB

The cartoon in Additional file 1: Figure S1 addresses the multiple alternative definitions of regulatory $\mathrm{T}$ cells and provides a heuristic overview of how these various subsets of $\mathrm{T}$ cells are related in ontogeny or in functional capacities. The percentage of $\mathrm{CD} 44^{+} \mathrm{CD} 25^{\text {high }} \mathrm{CD} 127^{-/ \mathrm{dim}}$ regulatory $\mathrm{T}$ cells and $\mathrm{CD} 4^{+} \mathrm{CD} 25^{-} \mathrm{CD} 69^{+}$regulatory $\mathrm{T}$ cells among $\mathrm{CD}^{+} \mathrm{T}$ cells were significantly higher in GBM compared to G-PB $(4.97 \% \pm 2.72 \%$ vs. $3.16 \% \pm 1.52 \%$, $\mathrm{n}=20, \mathrm{p}=0.001 ; 6.27 \% \pm 3.94 \%$ vs. $0.89 \% \pm 0.92 \%, \mathrm{p}<$ 0.001 , Figure $1 \mathrm{~A}, \mathrm{~B}$ and $\mathrm{C})$. No statistically significant differences were found between G-BM and G-PB in the proportions of $\mathrm{CD} 4{ }^{+} \mathrm{CD} 25^{\text {high }} \mathrm{CD} 62 \mathrm{~L}^{+}$regulatory $\mathrm{T}$ cells among $\mathrm{CD}^{+} \mathrm{T}$ cells $(2.54 \% \pm 2.23 \%$ vs. $3.41 \% \pm 2.89 \%$, $p=0.204$, Figure $1 C$ and $D)$. However, because of the significantly higher numbers of $\mathrm{CD}^{+} \mathrm{T}$ cells in G-PB compared to G-BM, the absolute numbers of $\mathrm{CD} 4^{+}$ $\mathrm{CD} 25^{\text {high }} \mathrm{CD} 127^{- \text {low }}$ regulatory $\mathrm{T}$ cells, $\mathrm{CD} 4^{+} \mathrm{CD} 25^{\text {high }}$ $\mathrm{CD}_{2} \mathrm{~L}^{+}$regulatory $\mathrm{T}$ cells and $\mathrm{CD} 4^{+} \mathrm{CD} 25^{-} \mathrm{CD} 69^{+}$ regulatory $\mathrm{T}$ cells were significantly lower in G-BM than in G-PB $(P<0.0001$, Figure $1 E)$.

Considering that CD62L (L-selectin) is an important $\mathrm{T}$-cell homing receptor as well as a marker for T-cell development and that CD69 is an important activating receptor that exerts regulatory functions in the immune response of $\mathrm{T}$ cells, we also compared differences in the expression of $\mathrm{CD} 62 \mathrm{~L}$ and $\mathrm{CD} 69$ on $\mathrm{CD} 4^{+} \mathrm{CD} 25^{\text {high }}$ $\mathrm{CD} 127^{-/ \text {low }}$ regulatory $\mathrm{T}$ cells between G-BM and G-PB. Although the expression of CD62L was comparable in
$\mathrm{CD} 4{ }^{+} \mathrm{CD} 25^{\text {high }} \mathrm{CD} 127^{- \text {low }}$ regulatory $\mathrm{T}$ cells $(59.88 \% \pm$ $25.07 \%$ vs. $54.96 \% \pm 20.71 \%$, Figure $1 \mathrm{~A}$ ), the expression of $\mathrm{CD} 69$ was significantly higher in $\mathrm{CD} 4{ }^{+} \mathrm{CD} 25^{\text {high }}$ CD127 $7^{- \text {low }}$ regulatory $\mathrm{T}$ cells in G-BM compared with G$\mathrm{PB}(2.38 \% \pm 2.21 \%$ vs. $0.78 \% \pm 0.50 \%, p=0.005$, Figure $1 \mathrm{~A})$. In addition, most of the $\mathrm{CD} 4{ }^{+} \mathrm{CD} 25^{\text {high }} \mathrm{CD} 62 \mathrm{~L}^{+}$regulatory $\mathrm{T}$ cells were CD127 negative. The percentage of CD127 negative cells among $\mathrm{CD} 44^{+} \mathrm{CD} 25^{\text {high }} \mathrm{CD} 62 \mathrm{~L}^{+}$regulatory $\mathrm{T}$ cells was comparable between G-BM and G-PB $(83.74 \% \pm$ $13.69 \%$ vs. $85.33 \% \pm 9.71 \%, \mathrm{p}=0.936)$. Therefore, the percentage of $\mathrm{CD} 4{ }^{+} \mathrm{CD} 25^{\text {high }} \mathrm{CD} 127^{-/ \text {dim }} \mathrm{CD} 62 \mathrm{~L}^{+}$regulatory $\mathrm{T}$ cells was significantly higher in G-BM compared to G-PB $(3.43 \% \pm 2.18 \%$ vs. $1.69 \% \pm 1.54 \%, p=0.006$, Figure $1 C)$.

A phenotypic analysis of the regulatory $\mathrm{T}$ cell compartment revealed 3 distinct Treg populations $\left(C D 45 \mathrm{RA}^{+}\right.$ $\mathrm{HLADR}^{-}, \mathrm{CD}^{4} 5 \mathrm{RA}^{-} \mathrm{HLADR}^{+}, \mathrm{CD}^{2} 5 \mathrm{RA}^{-} \mathrm{HLADR}^{-}$) in G-BM and G-PB [24]. The percentage of CD45RA ${ }^{+}$ HLADR $^{-}$naive Treg cells among the Treg cells was significantly higher in G-BM compared to G-PB $(29.26 \% \pm$ $15.50 \%$ vs. $18.06 \% \pm 10.85 \%, P=0.009$, Figure $2 \mathrm{~A}-\mathrm{B})$. However, the percentage of the CD45RA ${ }^{-} \mathrm{HLADR}^{+}$Treg subset $(34.01 \% \pm 9.17 \%$ vs. $37.61 \% \pm 7.99 \%, \quad \mathrm{P}=0.028)$ and the CD45RA ${ }^{-}$HLADR $^{-}$Treg subset $(35.15 \% \pm 8.98 \%$ vs. $43.83 \% \pm 7.20 \%, P=0.004$ ) was significantly lower in G-BM compared to G-PB (Figure 2A-B). We also observed that the expression of CCR7 in CD45RA ${ }^{+}$ $\mathrm{HLADR}^{-}$Treg cells was significantly higher than that in $\mathrm{CD}^{2} 5 \mathrm{RA}^{-} \mathrm{HLADR}^{+}$Treg or in CD45RA ${ }^{-} \mathrm{HLADR}^{-}$Treg cells (Figure 2C-D). The expression of CCR7 in Treg cells overall was comparable in G-BM and G-PB. However, the percentage of CCR7-expressing CD45RA ${ }^{+}$ HLADR $^{-}$naive Treg cells in G-BM was significantly lower compared to those in G-PB $(76.64 \% \pm 6.23 \%$ vs. $84.02 \% \pm 7.43 \%, \mathrm{P}=0.025$, Figure $2 \mathrm{C}-\mathrm{D}$ ), but the MFI of CCR7-expressing CD45RA ${ }^{+} \mathrm{HLADR}^{-}$naive Treg cells was comparable (Figure 2E).

The expression of Ki67 in $\mathrm{CD} 44^{+} \mathrm{CD} 25^{\text {high }} \mathrm{Foxp}^{+}$Treg cells was measured as a marker of cell proliferation. The results from the entire cohort of patients and a representative patient showed that $\mathrm{CD} 4^{+} \mathrm{CD} 25^{\text {high }} \mathrm{Foxp}^{+}$ Treg cells in G-BM had higher levels of proliferation than those in G-PB $(50.93 \% \pm 13.25 \%$ vs. $38.19 \% \pm 8.95 \%$, $\mathrm{P}=0.037$, Figure 3).

\section{Comparison of the in vitro suppression function of regulatory T cells between G-BM and G-PB}

To compare the suppressive activity of Treg cells between G-BM and G-PB, we performed additional functional studies. The suppression assay was performed with a dilution series ranging from a ratio of 1:1 to 4:1 of G-BM-Tresp cells:G-BM-Treg cells or of G-PB-Tresp cells:G-PB-Treg cells as outlined in Figure 4. As an additional control, GBM- or G-PB-Tresp were cultured alone with and without the Treg Suppression Inspector. In addition, G-BM-Treg 


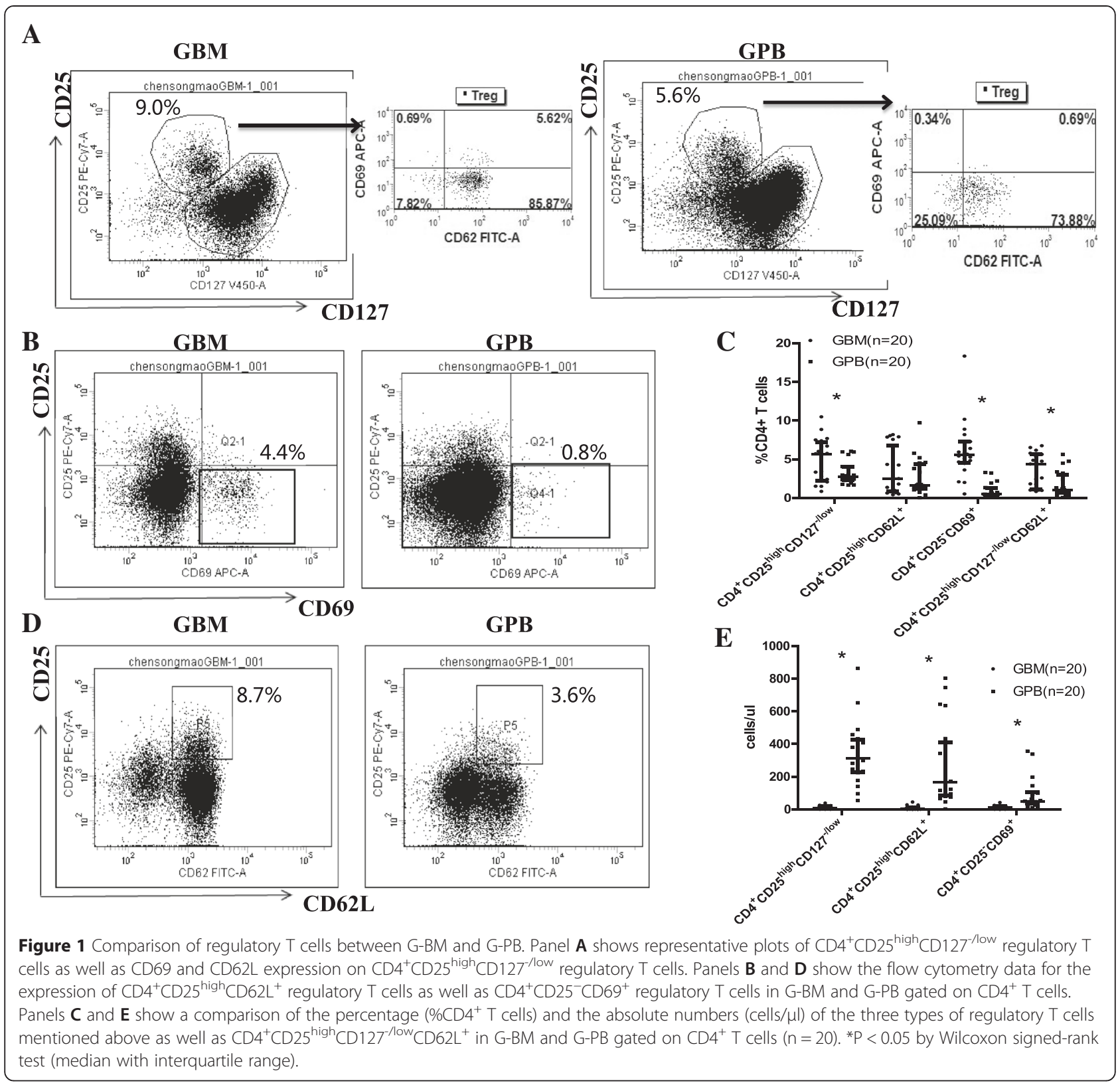

cells were also cocultured with equal numbers of G-PBTresp cells in comparison to G-PB-Treg cells cocultured with equal numbers of G-PB-Tresp cells. As shown for a representative patient in Figure 4A-H, Treg cells suppressed the proliferation of CFSE-labeled responder $\mathrm{T}$ cells from the same donor, achieving the maximum suppression at a 1:1 ratio of Tresp to Treg cells. At a 1:1 ratio of Tresp to Treg cells, no statistically significant differences were found in the suppression capability of Treg cells among G-BMTreg cocultured with G-BM-Tresp (70.13\% $\pm 15.12 \%)$, GBM-Treg cocultured with G-PB-Tresp $(47.63 \% \pm 14.73 \%)$, or G-PB-Treg cocultured with G-PB-Tresp $(51.36 \% \pm$ 22.29\%) (Figure 4I). Significant differences in the suppression rates were found at a G-BM Tresp:G-BM Treg ratio between $4: 1$ and $1: 1$ or $2: 1$ and $1: 1(P=0.043$ and $P=0.043$, respectively). Finally, a trend towards a higher suppression rate at a G-BM Tresp:G-BM Treg ratio of 2:1 compared to 4:1 $(\mathrm{P}=0.080)$ was observed (Figure $4 \mathrm{I})$.

\section{Comparison of the ratio of regulatory $T$ cells and effector T cells between G-BM and G-PB}

We found no statistically significant differences comparing G-BM and G-PB with respect to the proportions of CD4+ $\mathrm{T}$ cells with a conventional $\mathrm{T}$ cell phenotype $\left(\mathrm{CD} 4^{+}\right.$ $\mathrm{CD} 25^{\text {low }} \mathrm{CD} 127^{+} ; 75.60 \% \pm 5.41 \%$ vs. $73.99 \% \pm 7.97 \%, \mathrm{P}=$ 0.247 , Figure $5 \mathrm{~A})$ and Th17 cells $(3.86 \% \pm 1.96 \%$ vs. $2.79 \% \pm 1.40 \%, \mathrm{p}=0.126$, Figure $5 \mathrm{~B}$ ). The proportions of Th1 cells in $\mathrm{CD}_{4}^{+} \mathrm{T}$ cells were significantly higher in 


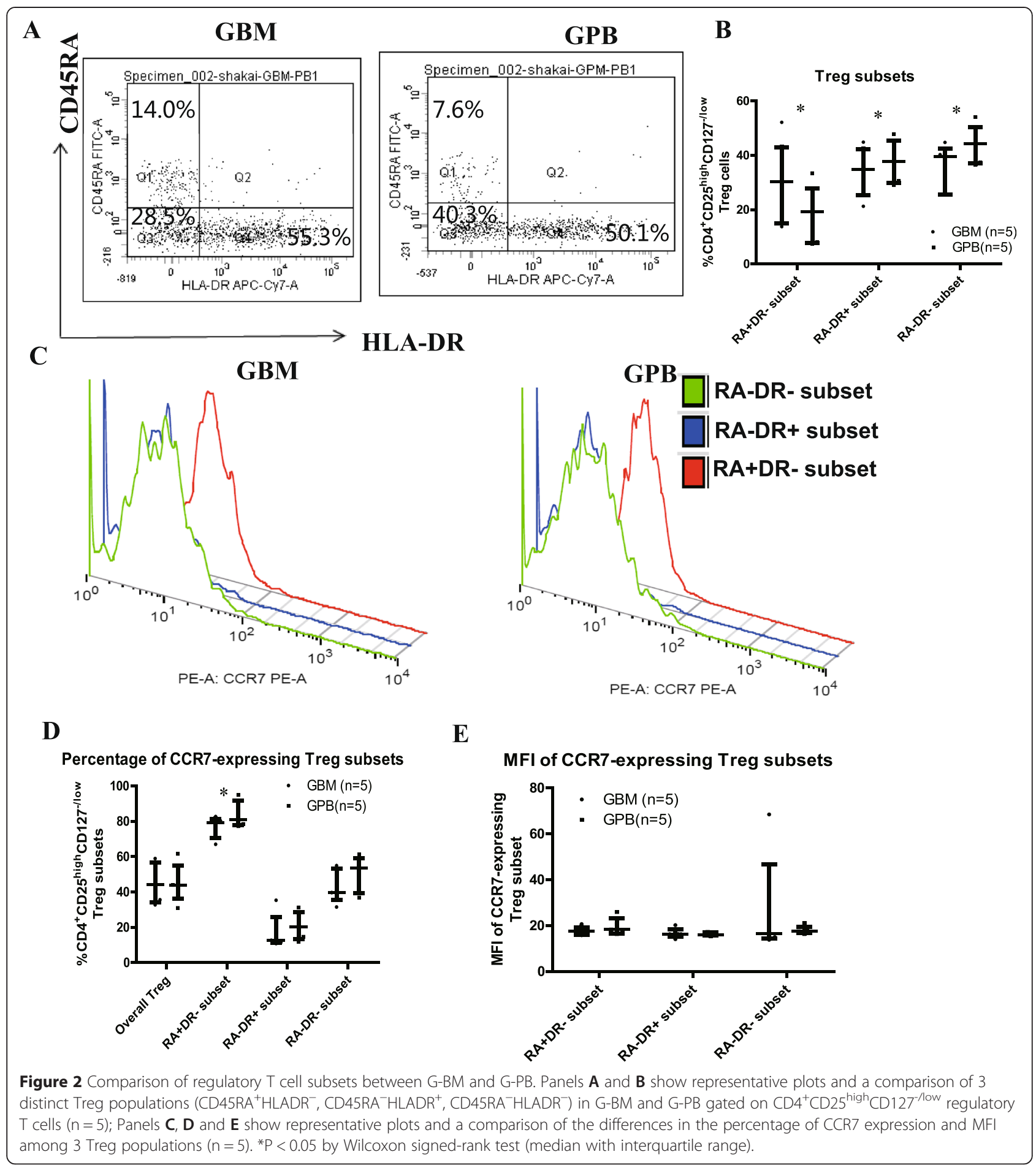

G-BM compared to G-PB $(39.51 \% \pm 12.49 \%$ vs. $25.17 \%$ $\pm 9.09 \%, p<0.001$, Figure $5 \mathrm{C})$. However, similar to the differences in regulatory $\mathrm{T}$ cells between G-BM and G$\mathrm{PB}$, the absolute numbers of conventional T cells, Th17 cells and Th1 cells were significantly lower in G-BM than those in G-PB $(\mathrm{P}<0.0001$, Figure 5D).
In addition to comparisons of individual subsets of $\mathrm{T}$ cells between G-BM and G-PB, it is important to examine the relative balance of the effector and regulatory arms of the immune system. The ratio of $\mathrm{CD} 44^{+} \mathrm{CD} 25^{\text {low }} \mathrm{CD} 127^{+}$ conventional $\mathrm{T}$ cells to $\mathrm{CD} 4^{+} \mathrm{CD} 25^{\text {high }} \mathrm{CD} 127^{- \text {llow }}$ regulatory $\mathrm{T}$ cells was significantly lower in G-BM compared to 


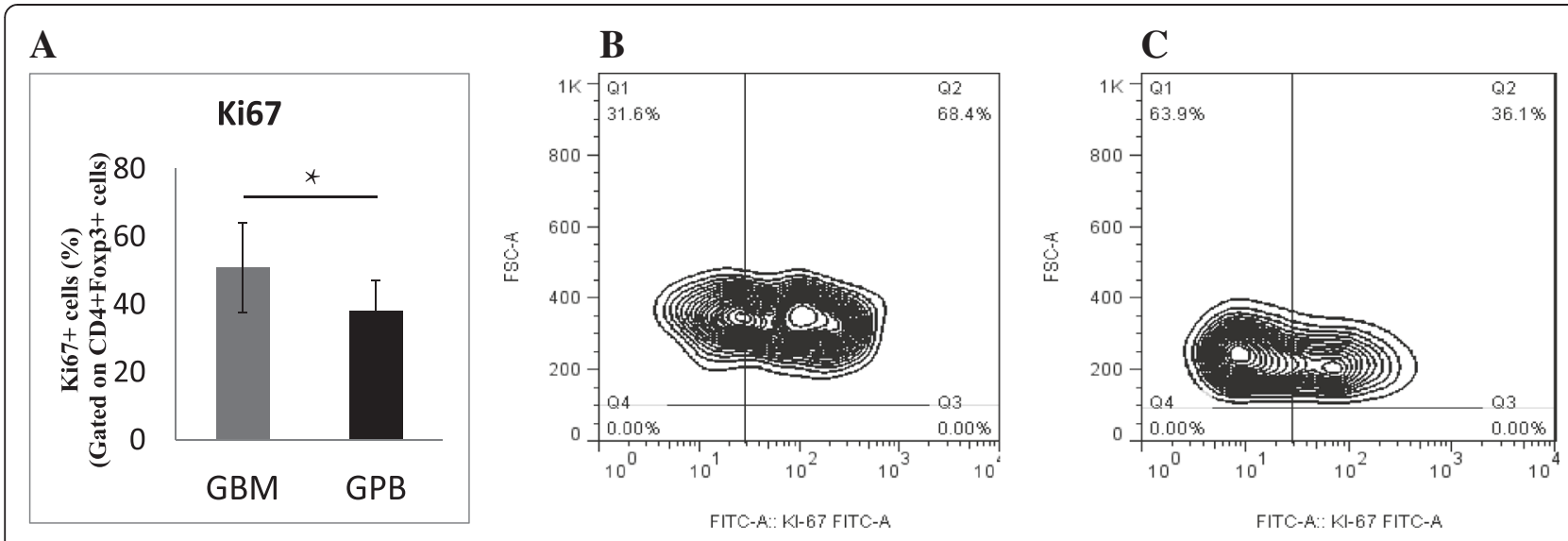

Figure 3 Comparison of the proliferation of regulatory T cell subsets between G-BM and G-PB. Panel A. Percentage of Ki67 expression on freshly separated CD4 $4^{+}$CD25 ${ }^{\text {high }}$ Foxp3 ${ }^{+}$Treg cells in G-BM and G-PB $(n=12)$. Panels $\mathbf{B}$ and $\mathbf{C}$. Flow cytometry plots (the percentage of Ki67 Treg cells is indicated above the boxes) from the representative G-BM (B) and G-PB (C). ${ }^{* P} \leq 0.05$ by Wilcoxon signed-rank test (mean \pm SD). FSC, forward scatter.

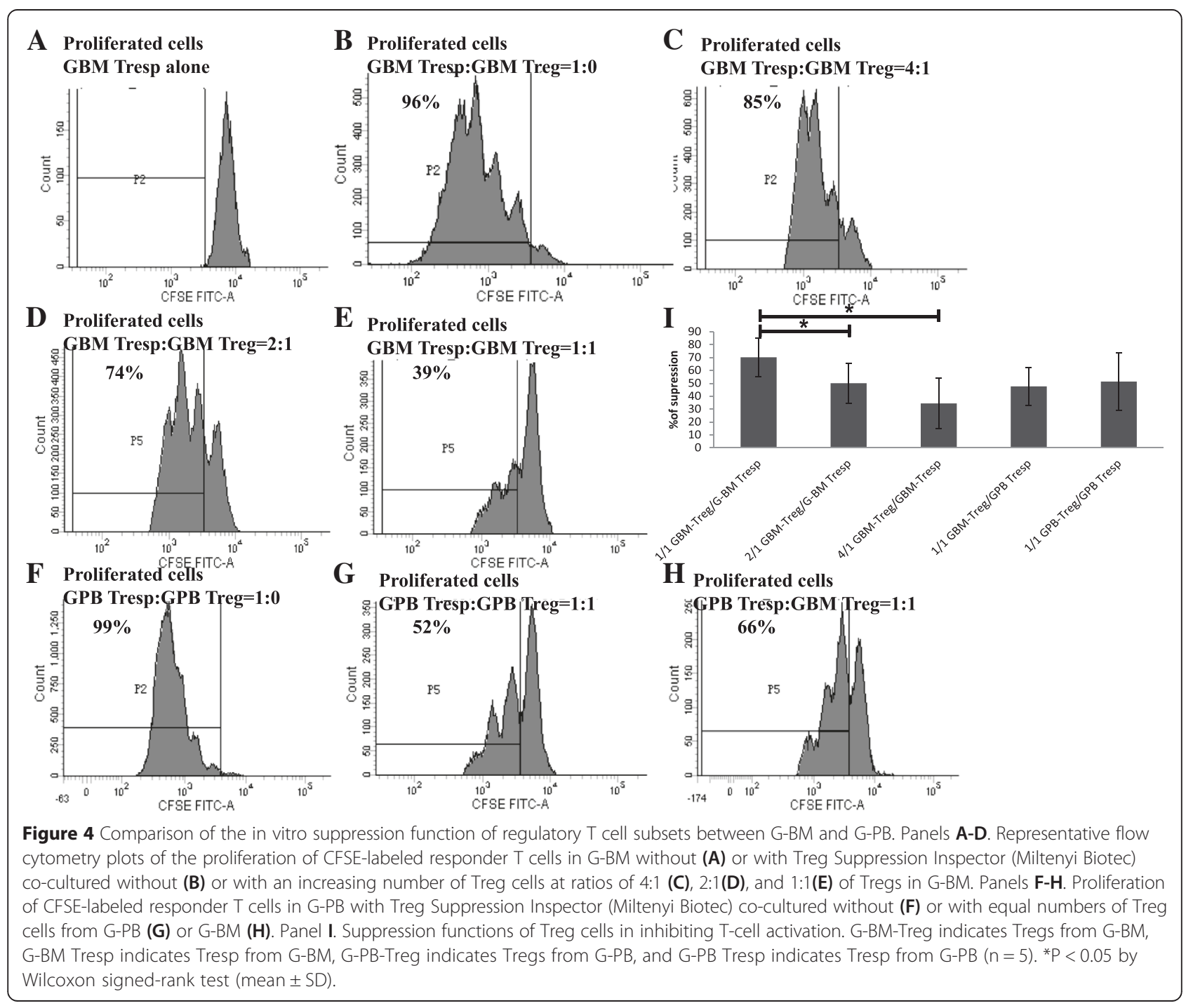



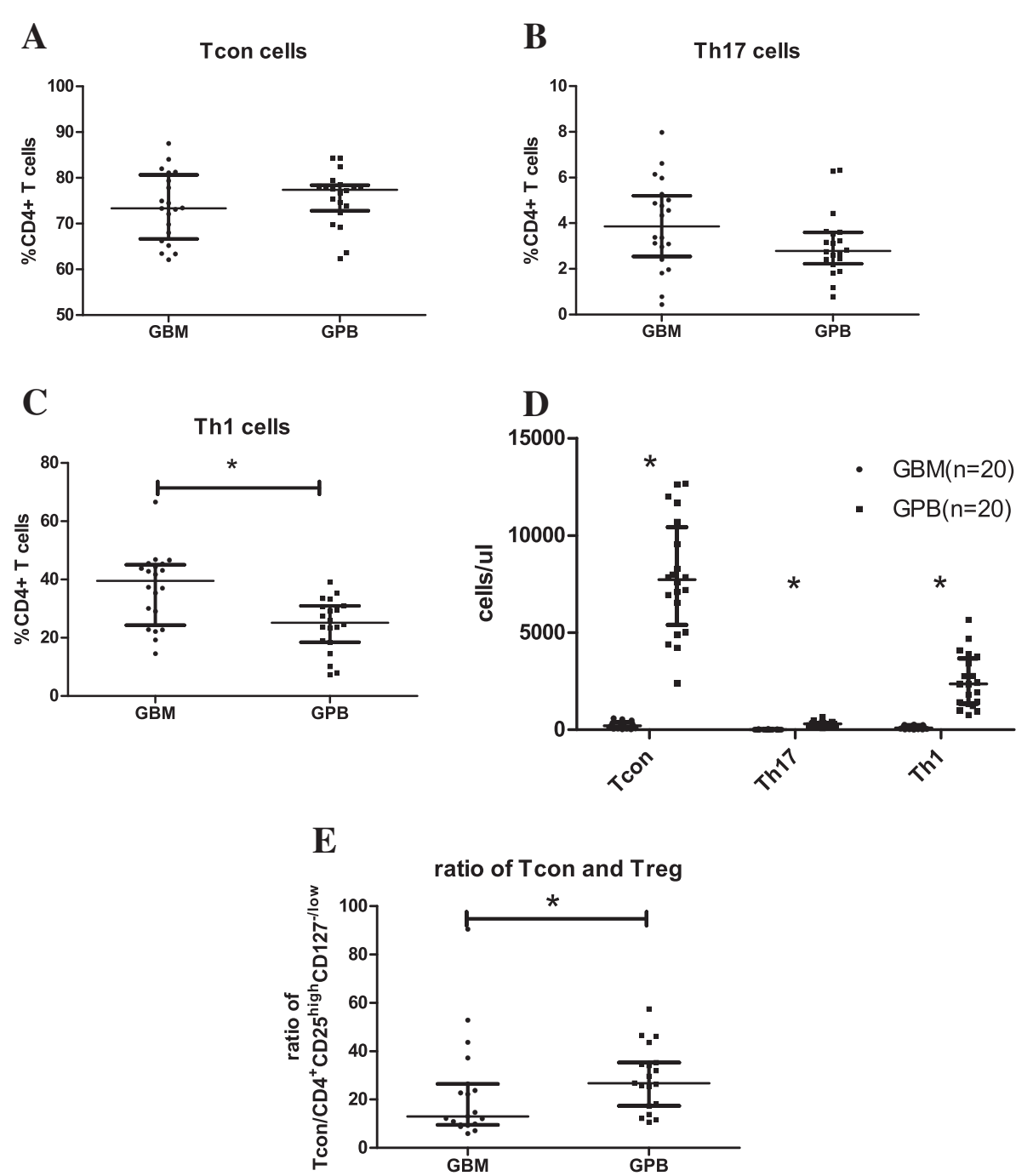

Figure 5 Comparison of effector T cells between G-BM and G-PB. Panels A-C show the percentage of CD25 $5^{\text {low/ }} \mathrm{CD} 127^{+}$expression $(\mathbf{A}$, Conventional T cells, Tcon), IL17 secretion (B, Th17 cells), and IFN- $\gamma$ secretion ( $\mathbf{C}$, Th1 cells) on freshly separated CD4 ${ }^{+}$cells in G-BM and G-PB $(n=20)$. Panel $\mathbf{D}$ shows the comparison of the absolute numbers (cells/ $\mu$ l) of Tcon, Th17, and Th1 cells between G-BM and G-PB $(n=20)$. Panel $\mathbf{E}$ shows the ratio of Tcon cells to $\mathrm{CD} 4^{+} \mathrm{CD} 25^{\text {high }} \mathrm{CD} 127^{- \text {Low }}$ Treg cells in G-BM and G-PB $(n=20) .{ }^{*} \mathrm{P} \leq 0.05$ by Wilcoxon signed-rank test (median with interquartile range).

that in G-PB $(22.27 \pm 20.55$ vs. $30.37 \pm 14.67, P=0.014$, Figure $5 \mathrm{E}$ ). In addition, the ratio of $\mathrm{CD} 44^{+} \mathrm{CD} 25^{\text {low }} \mathrm{CD} 127^{+}$ conventional $\mathrm{T}$ cells to $\mathrm{CD} 4{ }^{+} \mathrm{CD} 25^{\text {high }} \mathrm{CD} 127^{-/ \text {low }} \mathrm{CD} 62 \mathrm{~L}^{+}$ regulatory $\mathrm{T}$ cells was also lower in G-BM compared to that in G-PB $(35.28 \pm 29.11$ vs. $78.02 \pm 57.02, \mathrm{P}=0.008)$. The ratios of $\mathrm{Th} 17$ cells to $\mathrm{CD} 4{ }^{+} \mathrm{CD} 25^{\text {high }} \mathrm{CD} 127^{-/ \text {low }}$ regulatory $\mathrm{T}$ cells were comparable between $\mathrm{G}-\mathrm{BM}$ and G-PB $(P=0.970)$.

\section{Correlations of regulatory T cells between G-BM and G-PB} Positive correlations were found between the proportions of $\mathrm{CD} 44^{+} \mathrm{CD} 25^{\text {high }} \mathrm{CD} 127^{-/ \text {low }}$ regulatory $\mathrm{T}$ cells and $\mathrm{CD} 4{ }^{+} \mathrm{CD} 25^{\text {high }} \mathrm{CD} 62 \mathrm{~L}^{+}$regulatory $\mathrm{T}$ cells in $\mathrm{G}-\mathrm{BM}$ $(\mathrm{R}=0.758, \mathrm{P}<0.001$, Figure $6 \mathrm{~A})$ and in $\mathrm{G}-\mathrm{PB}(\mathrm{R}=$ $0.871, \mathrm{P}<0.001$, Figure $6 \mathrm{~B})$, but not for $\mathrm{CD} 4^{+} \mathrm{CD} 25^{-}$
$\mathrm{CD}^{2} 9^{+}$regulatory $\mathrm{T}$ cells in $\mathrm{G}-\mathrm{BM}(\mathrm{R}=0.385, \mathrm{P}=0.094)$ and in $\mathrm{G}-\mathrm{PB}(\mathrm{R}=0.134, \mathrm{P}=0.575)$.

Finally, positive correlations were found between G-BM and $\mathrm{G}-\mathrm{PB}$ in the proportions of $\mathrm{CD} 4{ }^{+} \mathrm{CD} 25^{\text {high }} \mathrm{CD} 127^{-/ \text {low }}$ regulatory $\mathrm{T}$ cells $(\mathrm{R}=0.625, \mathrm{P}=0.003$, Figure $6 \mathrm{C})$, the proportions of $\mathrm{CD} 4{ }^{+} \mathrm{CD} 25^{\text {high }} \mathrm{CD} 62 \mathrm{~L}^{+}$regulatory $\mathrm{T}$ cells $(\mathrm{R}=0.518, \mathrm{P}=0.019$, Figure $6 \mathrm{D})$, and the proportions of $\mathrm{CD} 4{ }^{+} \mathrm{CD} 25^{-} \mathrm{CD} 9^{+}$regulatory $\mathrm{T}$ cells $(\mathrm{R}=0.508, \mathrm{P}=0.022$, Figure 6E).

\section{Discussion}

This is the first study to explore the differences between G-BM and G-PB with regard to the Treg cell contents as well as the balance between effector $\mathrm{T}$ cells and regulatory $\mathrm{T}$ cells. Our data demonstrated that the proportions 


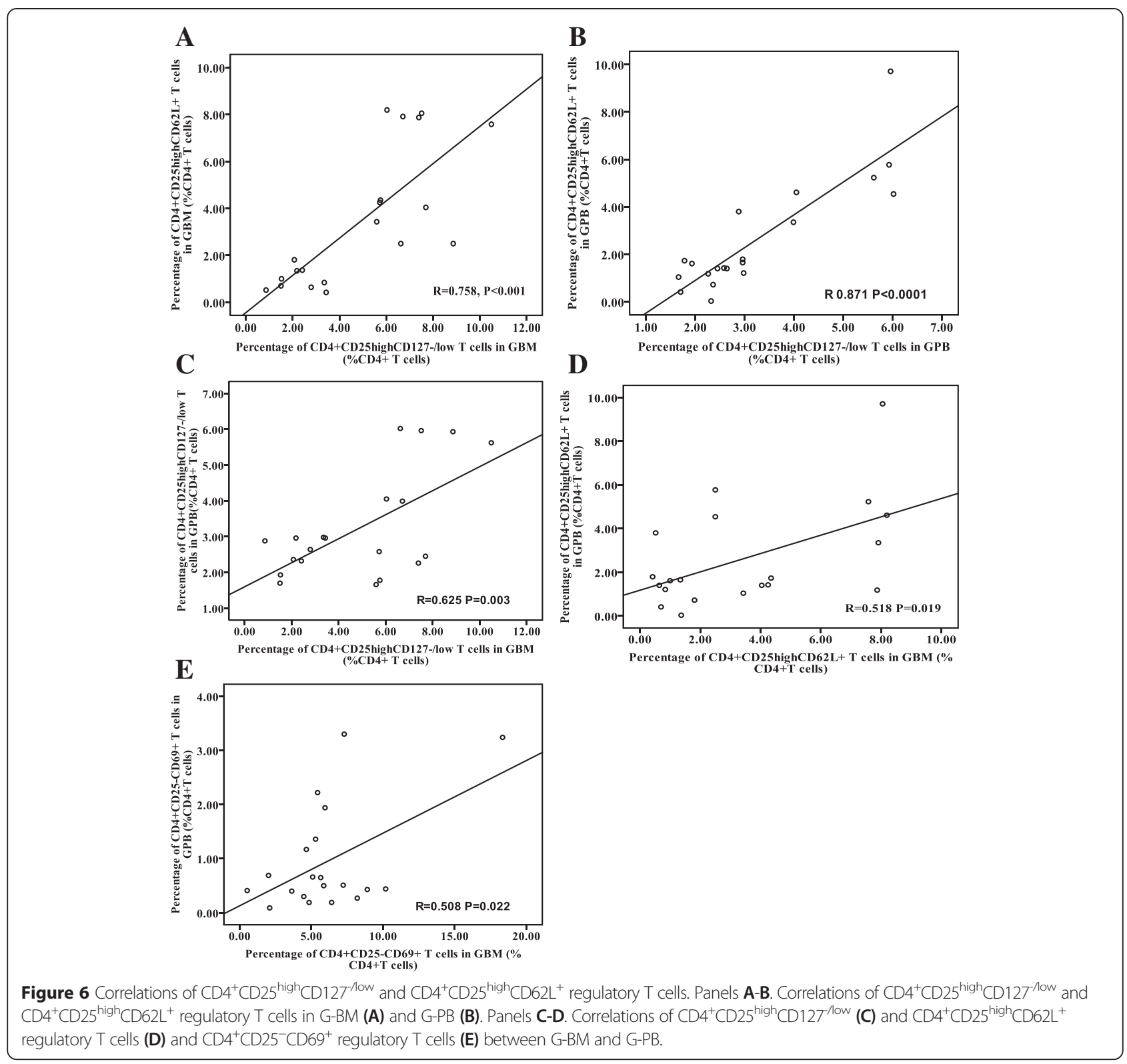

of conventional T cells and Th17 cells were comparable; however, the proportions of regulatory $\mathrm{T}$ cells and Th1 cells were significantly higher in G-BM compared to G-PB. Therefore, although the absolute number of regulatory $\mathrm{T}$ cells, conventional $\mathrm{T}$ cells, Th17 cells, or Th1 cells were significantly lower in G-BM compared to $\mathrm{G}-\mathrm{PB}$, the ratio of conventional $\mathrm{T}$ cells to $\mathrm{CD} 4^{+}$ CD $25^{\text {high }} \mathrm{CD} 127^{- \text {llow }}$ Treg cells was significantly lower in G-BM compared to G-PB, which could partially contribute to the lower incidence of acute GVHD in G-BM transplantation compared to G-PB transplantation.

The $\mathrm{CD} 44^{+} \mathrm{CD} 25^{\text {high }} \mathrm{CD} 127^{- \text {low }}$ Treg subsets could mediate peripheral $\mathrm{T}$-cell homeostasis and contribute to self-tolerance [25]. Not only the frequencies of $\mathrm{CD} 4^{+}$ CD25 ${ }^{\text {high }} \mathrm{CD} 127^{- \text {/low }}$ Treg cells but also those of $\mathrm{CD} 4^{+}$
CD25 ${ }^{\text {high }} \mathrm{CD} 127^{-/ \text {low }} \mathrm{CD} 62 \mathrm{~L}^{+}$Treg cells were significantly higher in G-BM compared to G-PB. In addition, the fraction of proliferating $\mathrm{CD} 4^{+} \mathrm{CD} 25^{\text {high }} \mathrm{Foxp}^{+} \mathrm{T}$ cells was significantly higher in G-BM than in G-PB, which might contribute to the higher frequencies of regulatory $\mathrm{T}$ cells in G-BM compared to G-PB. Zou WP and colleagues demonstrated that the bone marrow is a reservoir for $\mathrm{CD} 4{ }^{+} \mathrm{CD} 25^{+}$regulatory $\mathrm{T}$ cells that traffic by means of CXCL12/CXCR4 signaling. G-CSF reduces the expression of human bone marrow CXCL12 in vivo, which is associated with the mobilization of bone marrow Treg cells to the peripheral blood in human volunteers [17]. Boyer $\mathrm{O}$ and colleagues found that the frequencies of Treg cells were still significantly lower in G-PB compared to BM transplants. In addition, G-CSF administration and 
leukapheresis were found to contribute to the loss of the $\mathrm{CD} 2 \mathrm{~L}^{+}$Treg cell subset [16]. Consistent with Boyer O et al., our data demonstrated that the expression of CD62L on $\mathrm{CD} 44^{+} \mathrm{CD} 25^{\text {high }} \mathrm{CD} 127^{- \text {low }}$ Treg cells was comparable in G-PB or in G-BM, confirming that G-CSF administration contributes to the loss of CD62L on Treg cells. In addition, the lower levels of CCR7 in CD45RA ${ }^{+}$ HLADR $^{-}$Treg cells in G-BM also indicate a regulatory influence of G-CSF on human Treg-cell migration and suggests a role in the redistribution of Treg cell subsets to the peripheral blood, involving CD62L, CCR7, and CXCL12/CXCR4 signals. It has been suggested that $\mathrm{CD} 6 \mathrm{~L}^{+}$Treg cells may have higher immunosuppressive properties in vitro than $\mathrm{CD}^{2} 2 \mathrm{~L}^{-}$Treg cells [10] and possess the capacity to control GVHD [11,26]. CD69 deficiency leads to diminished levels of TGF- $\beta$ that contribute to an enhanced immune response, resulting in increased inflammation in a collagen-induced arthritis model $[12,27]$. Therefore, our data suggested that the higher frequencies of $\mathrm{CD} 4{ }^{+} \mathrm{CD} 25^{\text {high }} \mathrm{CD} 127^{-/ \text {low }} \mathrm{CD} 62 \mathrm{~L}^{+}$Treg cells as well as the higher expression of CD69 on Treg cells in G-BM would help maintain the hyporesponsiveness of G-BM compared to G-PB. In addition, distinct human Treg subsets have been described by analyzing cell-surface markers, such as CD45RA and HLADR. Of these, only the CD45RA ${ }^{+}$naive cells within the CD4 + CD25 high T-cell compartment were involved, as only this subpopulation homogeneously expressed CD62L, CCR7, cytotoxic $\mathrm{T}$ lymphocyte-associated antigen-4 (CTLA-4), and FOXP3, produced no inflammatory cytokines and maintained robust suppressive activity after expansion [28]. The Treg compartment in patients developing acute GVHD also showed a marked depletion of CD45RA ${ }^{+}$HLADR $^{-“ n a i v e " ~ T r e g ~ c e l l s ~ c o m-~}$ pared with tolerant patients [24]. Therefore, the higher percentage of "naive" Treg cells in G-BM compared to those in G-PB might indicate higher immunosuppressive properties. However, the results of the in vitro Treg cell suppression assay were comparable between G-BM and G-PB. The limited number of samples studied and the selection of CD4+ CD25+ Tregs using the Regulatory T cell Isolation kit (Miltenyi Biotec) rather than fluorescenceactivated cell sorting might affect the cell suppressive activities reported herein. In addition, an imbalance in the effector and regulatory CD4 $\mathrm{T}$ cells is associated with GVHD after HSCT using a reduced intensity conditioning regimen and alemtuzumab [29]. The high frequency of $\mathrm{CD} 4^{+} \mathrm{CD} 25^{-} \mathrm{CD} 69^{+} \mathrm{T}$ cells is correlated with a low risk of acute GVHD in allotransplants [8]. Thus, the higher ratio of Tregs to conventional $\mathrm{T}$ cells as well as higher frequencies of $\mathrm{CD} 4^{+} \mathrm{CD} 25^{-} \mathrm{CD} 69^{+} \mathrm{T}$ cells in G-BM compared to G-PB would support the lower occurrence of acute GVHD post-G-BM transplantation compared to G-PB transplantation [2].
Correlations were found in $\mathrm{CD} 4{ }^{+} \mathrm{CD} 25^{\text {high }} \mathrm{CD} 127^{- \text {llow }}$ Treg cells and $\mathrm{CD} 4{ }^{+} \mathrm{CD} 25^{\text {high }} \mathrm{CD} 62 \mathrm{~L}^{+}$Treg cells but not in $\mathrm{CD} 4^{+} \mathrm{CD} 25^{-} \mathrm{CD} 69^{+} \mathrm{T}$ cells between G-BM and G-PB, suggesting that the $\mathrm{CD} 4^{+} \mathrm{CD} 25^{\text {high }} \mathrm{CD} 127^{- \text {low }}$ Treg cells and $\mathrm{CD} 4{ }^{+} \mathrm{CD} 25^{\text {high }} \mathrm{CD} 62 \mathrm{~L}^{+}$Treg cells in G-PB might derive from $\mathrm{BM}$ and might overlap each other; however, the development of $\mathrm{CD} 4^{+} \mathrm{CD} 25^{-} \mathrm{CD} 69^{+} \mathrm{T}$ cells in G-PB had no direct relevance to those in G-BM, which will need to be confirmed in the future.

Although acute GVHD has been classically assumed to be Th1-mediated on the basis of findings in animal models, we now face a more complex scenario involving possible roles of newly identified Th17 cells as well as Treg cells in GVHD [30]. The differential expression of chemokine receptors and selectin ligands on each Th subset may ensure the unique ability of each Th subset to induce tissue-specific GVHD [31], and the absence of regulatory T-cell control of Th1 and Th17 cells is responsible for the autoimmune-mediated pathology in chronic graft-versus-host disease [32]. Thus, it appears that a delicate balance among Th1, Th2, Th17, and Treg cells after transplantation is an important determinant of the severity, manifestation, and tissue distribution of GVHD. In this study, the ratio of Th17 cells and Treg cells were comparable between G-BM and G-PB, but the percentages of Th1 in G-BM were higher compared with G-PB. It is not clear whether the Th1 cells could contribute to the prevention or initiation of GVHD posttransplantation $[33,34]$. Yi et al. have demonstrated that the absence of Th17 cells leads to augmented Th1 differentiation and exacerbated acute GVHD [31]. Waller et al. showed that donor bone marrow precursors of plasmacytoid dendritic cells (pre-pDCs) can activate donor T cells toward Th1 immune polarization, then induce indoleamine 2,3-dioxygenase synthesis to limit GVHD by altering the balance between donor Treg and inflammatory $\mathrm{T}$ cells [33]. A better understanding of the dynamic process of reciprocal differentiation of Th and regulatory cell subsets as well as their complex interactions would help establish novel graft engineering that modulates the fine balance between Th and Treg subsets to improve the outcome of allo-HSCT.

\section{Conclusions}

In summary, this study demonstrated that higher frequencies of regulatory $\mathrm{T}$ cells and a decreased ratio of effector $\mathrm{T}$ cells to regulatory $\mathrm{T}$ cells in G-BM would lay part of the immunological groundwork for a lower occurrence of acute or chronic GVHD post-G-BM transplantation compared to G-PB transplantation. Conducting a large cohort study in a prospective manner would be warranted to compare the different clinical outcomes between G-BM and G-PB transplants and their correlation with different Th and Treg subsets within G-BM or G-PB allografts. 


\section{Additional file}

Additional file 1: Figure S1. The functional capacities and ontogeny relationships among different regulatory $T$ cells. A common ontogenic pathway might exist between the $\mathrm{CD} 4{ }^{+} \mathrm{CD} 25^{\text {high }} \mathrm{CD} 62 \mathrm{~L}^{+}$regulatory $\mathrm{T}$ cells and $\mathrm{CD} 4^{+} \mathrm{CD} 25^{\text {high }} \mathrm{CD} 127^{- \text {llow }}$ regulatory T cells. Both $\mathrm{CD} 4^{+} \mathrm{CD} 25^{\text {high }} \mathrm{CD} 62 \mathrm{~L}^{+}$ regulatory $T$ cells and $C D 4^{+} C D 25^{\text {high }} \mathrm{CD} 127^{- \text {llow }}$ regulatory $T$ cells can originate from the thymus or mature $\mathrm{CD} 4^{+} \mathrm{CD} 25^{\text {high }} \mathrm{T}$ lymphocytes, and there may be overlap between these two regulatory $T$ cells populations. A phenotypic analysis of the $\mathrm{CD} 4{ }^{+} \mathrm{CD} 25^{\text {high }} \mathrm{CD} 127^{- \text {low }}$ regulatory $T$ cell compartment

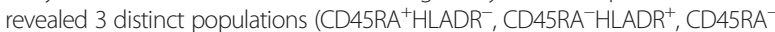
HLADR ${ }^{-}$. $\mathrm{CD}^{+} \mathrm{CD}^{-} 5^{-} \mathrm{CD} 69^{+} \mathrm{T}$ cells are generated from mature $\mathrm{CD} 4^{+} \mathrm{CD} 25^{-}$ T lymphocytes after TGF- $\beta$ induction. CD69 can be persistently expressed by these cells without CD25 expression. All of these three regulatory $T$ cells populations can inhibit effector $T$ cell function to reduce inflammation and therefore play immunoregulatory roles.

\section{Competing interests}

The authors declare that they have no competing interests.

\section{Authors' contributions}

$X Y Z$ conducted the flow cytometry assays, performed the statistical analyses and drafted the manuscript. YTW also conducted the flow cytometry assays and participated in data analyses. $\mathrm{XJH}$ participated in the design of the study and critically revised the study for important intellectual content. All other authors were involved in the study design, the discussions and the treatment of patients at Peking University Institute of Hematology. All authors read and approved the final manuscript.

\section{Acknowledgments}

This study was supported by grants from the National Natural Science Foundation of China (Grant No. 81270644 and 81230013), the Major State Basic Research Development Program of China (973 Program No. 2013CB733700), and doctoral funding from The Ministry of Education of China (grant no. 20110001110039), and Milstein Medical Asian American Partnership (MMAAP) Foundation Research Project Award in Hematology. The study was also partially supported by the Collaborative Innovation Center of Hematology, Peking University, China. The authors thank the members of the core facilities at the Peking University Institute of Hematology for the sample collection.

Received: 28 July 2014 Accepted: 27 April 2015

\section{Published online: 07 May 2015}

\section{References}

1. Korngold R, Sprent J. Lethal graft-versus-host disease after bone marrow transplantation across minor histocompatibility barriers in mice. Prevention by removing mature T cells from marrow. J Exp Med. 1978;148(6):1687-98.

2. Morton J, Hutchins C, Durrant S. Granulocyte-colony-stimulating factor (G-CSF)-primed allogeneic bone marrow: significantly less graft-versus-host disease and comparable engraftment to G-CSF-mobilized peripheral blood stem cells. Blood. 2001;98(12):3186-91.

3. Fontenot JD, Rasmussen JP, Williams LM, Dooley JL, Farr AG, Rudensky AY. Regulatory $T$ cell lineage specification by the forkhead transcription factor foxp3. Immunity. 2005;22(3):329-41.

4. Rezvani K, Mielke S, Ahmadzadeh M, Kilical Y, Savani BN, Zeilah J, et al. High donor FOXP3-positive regulatory T-cell (Treg) content is associated with a low risk of GVHD following HLA-matched allogeneic SCT. Blood. 2006;108(4):1291-7.

5. Pabst C, Schirutschke $H$, Ehninger G, Bornhauser M, Platzbecker U. The graft content of donor T cells expressing gamma delta TCR+ and CD4 + foxp3+ predicts the risk of acute graft versus host disease after transplantation of allogeneic peripheral blood stem cells from unrelated donors. Clin Cancer Res. 2007;13(10):2916-22

6. Wolf D, Wolf AM, Fong D, Rumpold H, Strasak A, Clausen J, et al. Regulatory T-cells in the graft and the risk of acute graft-versus-host disease after allogeneic stem cell transplantation. Transplantation. 2007;83(8):1107-13.

7. Vela-Ojeda J, Montiel-Cervantes L, Granados-Lara P, Reyes-Maldonado E, Garcia-Latorre E, Garcia-Chavez J, et al. Role of CD4 + CD25 + highFoxp3 +
CD62 $\mathrm{L}+$ regulatory $T$ cells and invariant NKT cells in human allogeneic hematopoietic stem cell transplantation. Stem Cells Dev. 2010;19(3):333-40.

8. Lu SY, Huang XJ, Liu KY, Liu DH, Xu LP. High frequency of CD4+ CD25-CD69+ $T$ cells is correlated with a low risk of acute graft-versus-host disease in allotransplants. Clin Transplant. 2012;26(2):E158-67.

9. Cohen JL, Trenado A, Vasey D, Klatzmann D, Salomon BL. CD4 + CD25+ immunoregulatory T cells: new therapeutics for graft-versus-host disease. J Exp Med. 2002;196(3):401-6.

10. Fu S, Yopp AC, Mao X, Chen D, Zhang N, Chen D, et al. CD4+ CD25+ CD62+ T-regulatory cell subset has optimal suppressive and proliferative potential. Am J Transplant. 2004;4(1):65-78.

11. Ermann J, Hoffmann P, Edinger M, Dutt S, Blankenberg FG, Higgins JP, et al. Only the CD62L+subpopulation of CD4 + CD25+ regulatory $T$ cells protects from lethal acute GVHD. Blood. 2005;105(5):2220-6.

12. Sancho D, Gomez M, Sanchez-Madrid F. CD69 is an immunoregulatory molecule induced following activation. Trends Immunol. 2005;26(3):136-40

13. Han Y, Guo Q, Zhang M, Chen Z, Cao X. CD69+ CD4+ CD25- T cells, a new subset of regulatory $T$ cells, suppress $T$ cell proliferation through membrane-bound TGF-beta 1. J Immunol. 2009;182(1):111-20.

14. Jun HX, Jun CY, Yu ZX. In vivo induction of T-cell hyporesponsiveness and alteration of immunological cells of bone marrow grafts using granulocyte colony-stimulating factor. Haematologica. 2004;89(12):1517-24.

15. Chen SH, Li X, Huang XJ. Effect of recombinant human granulocyte colony-stimulating factor on T-lymphocyte function and the mechanism of this effect. Int J Hematol. 2004;79(2):178-84.

16. Blache C, Chauvin JM, Marie-Cardine A, Contentin N, Pommier P, Dedreux I, et al. Reduced frequency of regulatory $T$ cells in peripheral blood stem cell compared to bone marrow transplantations. Biol Blood Marrow Transplant. 2010;16(3):430-4.

17. Zou L, Barnett B, Safah H, Larussa VF, Evdemon-Hogan M, Mottram P, et al. Bone marrow is a reservoir for CD4 + CD25+ regulatory T cells that traffic through CXCL12/CXCR4 signals. Cancer Res. 2004;64(22):8451-5.

18. Jun $H X$, Jun $C Y, Y u Z X$. A direct comparison of immunological characteristics of granulocyte colony-stimulating factor (G-CSF)-primed bone marrow grafts and G-CSF-mobilized peripheral blood grafts. Haematologica. 2005:90(5):715-6.

19. Chang YJ, Zhao XY, Huo MR, Huang XJ. Expression profiles of adhesion molecules on naive T cells in bone marrow grafts of healthy donors treated with granulocyte colony-stimulating factor. Transpl Immunol. 2009;21(4):228-33.

20. Huang XJ, Liu DH, Liu KY, Xu LP, Chen H, Han W, et al. Haploidentical hematopoietic stem cell transplantation without in vitro T-cell depletion for the treatment of hematological malignancies. Bone Marrow Transplant. 2006;38(4):291-7.

21. Lu DP, Dong L, Wu T, Huang XJ, Zhang MJ, Han W, et al. Conditioning including antithymocyte globulin followed by unmanipulated HLAmismatched/haploidentical blood and marrow transplantation can achieve comparable outcomes with HLA-identical sibling transplantation. Blood. 2006;107(8):3065-73.

22. Zhao XY, Lv M, Xu LL, Qian X, Huang XJ. Donor Th17 cells and IL-21 may contribute to the development of chronic graft-versus-host disease after allogeneic transplantation. Eur J Immunol. 2013;43(3):838-50.

23. Zhao XY, Xu LL, Lu SY, Huang XJ. IL-17-producing T cells contribute to acute graft-versus-host disease in patients undergoing unmanipulated blood and marrow transplantation. Eur J Immunol. 2011;41(2):514-26.

24. Dong S, Maiella S, Xhaard A, Pang Y, Wenandy L, Larghero J, et al. Multiparameter single-cell profiling of human CD4 + FOXP3 + regulatory T-cell populations in homeostatic conditions and during graft-versus-host disease. Blood. 2013;122(10):1802-12.

25. Beres AJ, Drobyski WR. The role of regulatory $T$ cells in the biology of graft versus host disease. Front Immunol. 2013;4:163.

26. Taylor PA, Panoskaltsis-Mortari A, Swedin JM, Lucas PJ, Gress RE, Levine BL, et al. L-Selectin(hi) but not the L-selectin(lo) CD4 + 25+ T-regulatory cells are potent inhibitors of GVHD and BM graft rejection. Blood. 2004;104(12):3804-12.

27. Sancho D, Gomez M, Viedma F, Esplugues E, Gordon-Alonso M, GarciaLopez MA, et al. CD69 downregulates autoimmune reactivity through active transforming growth factor-beta production in collagen-induced arthritis. J Clin Invest. 2003;112(6):872-82.

28. Hoffmann P, Eder R, Boeld TJ, Doser K, Piseshka B, Andreesen R, et al. Only the CD45RA+ subpopulation of CD4 + CD25high T cells gives rise to homogeneous regulatory $\mathrm{T}$-cell lines upon in vitro expansion. Blood. 2006;108(13):4260-7. 
29. Matthews K, Lim Z, Afzali B, Pearce L, Abdallah A, Kordasti S, et al. Imbalance of effector and regulatory CD4 T cells is associated with graft-versus-host disease after hematopoietic stem cell transplantation using a reduced intensity conditioning regimen and alemtuzumab. Haematologica. 2009;94(7):956-66.

30. Teshima T. Th1 and Th17 join forces for acute GVHD. Blood. 2011;118(18):4765-7.

31. Yi T, Zhao D, Lin C-L, Zhang C, Chen Y, Todorov I, et al. Absence of donor Th17 leads to augmented Th1 differentiation and exacerbated acute graft-versus-host disease. Blood. 2008;112(5):2101-10.

32. Chen X, Vodanovic-Jankovic S, Johnson B, Keller M, Komorowski R, Drobysk WR. Absence of regulatory T-cell control of TH1 and TH17 cells is responsible for the autoimmune-mediated pathology in chronic graft-versus-host disease. Blood. 2007;110(10):3804-13.

33. Lu Y, Giver CR, Sharma A, Li JM, Darlak KA, Owens LM, et al. IFN- $\gamma$ and indoleamine 2,3-dioxygenase signaling between donor dendritic cells and $T$ cells regulates graft versus host and graft versus leukemia activity. Blood. 2012;119(4):1075-85.

34. Lu Y, Waller EK. Dichotomous role of interferon-gamma in allogeneic bone marrow transplant. Biol Blood Marrow Transplant. 2009;15(11):1347-53.

\section{Submit your next manuscript to BioMed Central and take full advantage of:}

- Convenient online submission

- Thorough peer review

- No space constraints or color figure charges

- Immediate publication on acceptance

- Inclusion in PubMed, CAS, Scopus and Google Scholar

- Research which is freely available for redistribution 